\title{
Jesenov ožig, Chalara fraxinea
}

\section{Nikica OGRIS}

Jesenov ožig smo v Sloveniji ugotovili leta 2006 in sicer najprej v severovzhodnem in severnem predelu. V letu 2008 ga opažamo že po vsej državi. Intenziteta pojava je $\mathrm{v}$ različnih predelih različna. Bolezen lahko drastično uničuje mladje velikega jesena (slika 4) in prav tako odrasla drevesa (slika 3). Do zdaj so bolezen potrdili na velikem jesenu ( $F$. excelsior) in na ozkolistnem jesenu ( $F$. angustifolia). Na malem jesenu ( $F$. ornus) bolezni še nismo našli.

GIS je odvzel vzorce iz 23 lokacij iz 11 GGO. Na večini lokacij je prisotnost glive Chalara fraxinea potrjena $\mathrm{z}$ izolatom v čisto kulturo (slika 1). GIS bo vzorčil jesenov ožig še v GGO Novo mesto, Bled in Sežana, od koder še nima izolata glive. Vodje odsekov za gojenje in varstvo gozdov za slednje GGO prosimo, da nam sporočijo lokacijo, kjer se jim suši naravno mladje velikega jesena $z$ znamenji vidnega venenja listov (slika 4).

GIS intenzivno izvaja raziskave o tej novi bolezni velikega jesena za Slovenijo in za celo Evropo. Izvedli smo test patogenosti glive Chalara fraxinea. Test je

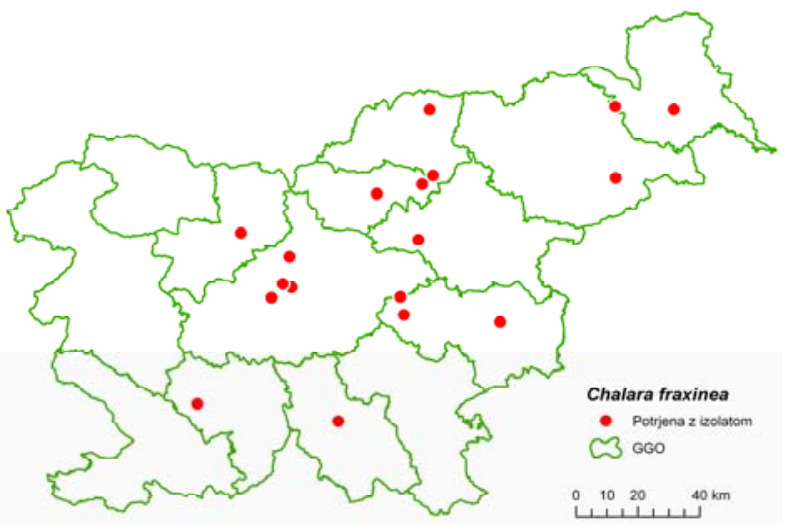

Slika 1: Karta potrjene razširjenosti jesenovega ožiga v Sloveniji in mesta odvzema vzorcev

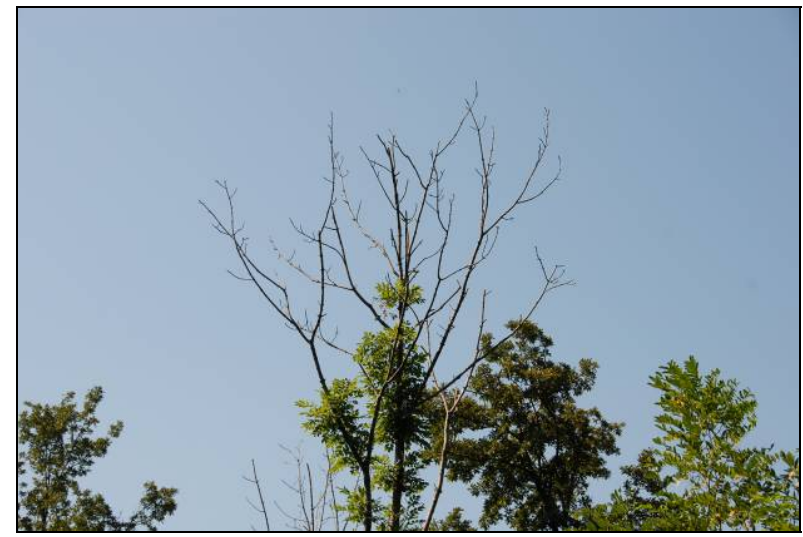

Slika 3: Močno prizadeta krošnja velikega jesena najverjetneje zaradi jesenovega ožiga pokazal, da je gliva močno patogena, še posebej $\mathrm{v}$ novih - letošnjih poganjkih (slika 2). Gliva se hitreje širi v lesu kot v skorji. Iz opazovanj na terenu smo ugotovili, da je intenziteta jesenovega ožiga močnejša prav na jesenovih rastiščih, t. j. na vlažnih tleh (ob rekah, potokih), veliki relativni zračni vlažnosti, tam kjer so nekoliko nižje temperature in ni direktnega sonca. $\mathrm{Na}$ mestih, kjer je vlažnost tal manjša, več direktne svetlobe in so višje temperature pa je intenziteta bolezni manjša. V takšnih razmerah se pogosto razvije rak, ki kaže na to, da se rastlina uspešno zoperstavlja patogenu.

Da je jesenov ožig treba jemati resno pove podatek, da se je v Litvi v dobrih 10. letih posušilo ok. $70 \%$ velikega jesena in to odraslih dreves. Ker bolezen uničuje pomladek in odrasla drevesa, obstaja nevarnost, da bo jesen tudi v Sloveniji kmalu močno prizadet. V predelih, kjer bo jesenov ožig zelo ogrozil obstoj velikega jesena, predlagamo, da veliki jesen postopoma nadomeščate $\mathrm{z}$ gorskim javorom.
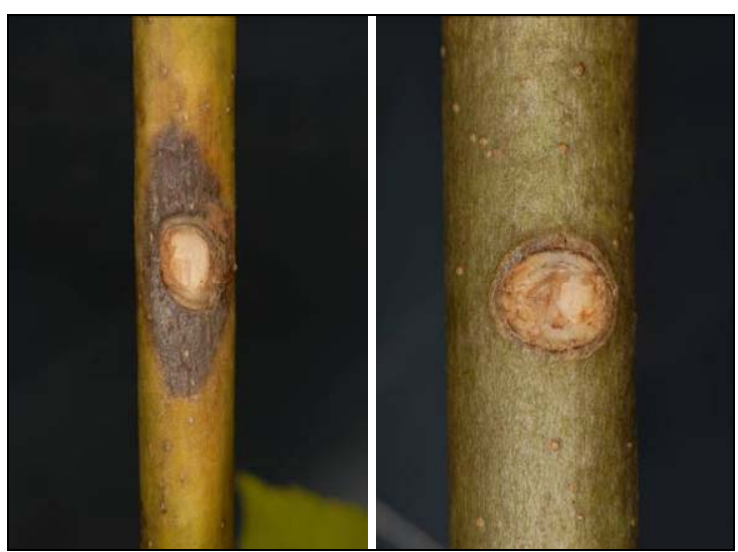

Slika 2: (slika levo) Nekroza, ki jo povzroči gliva Chalara fraxinea na letošnjih poganjkih velikega jesena 4 tedne po inokulaciji; (slika desno) zaceljena kontrola

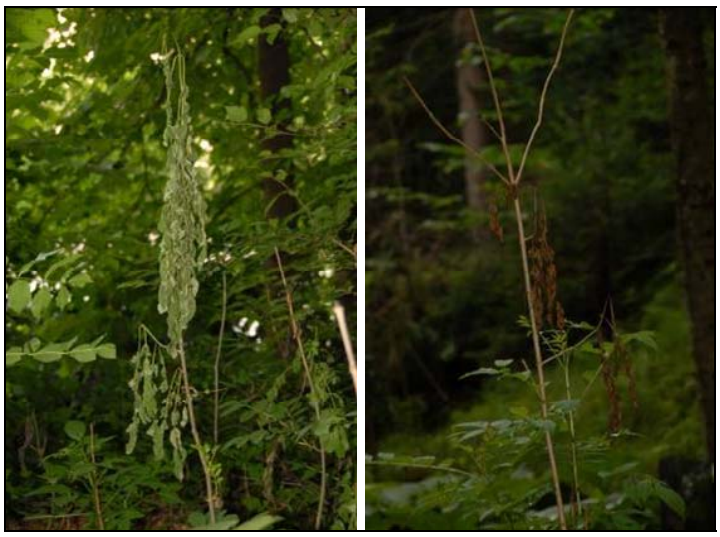

Slika 4: Najbolj pogost simptom jesenovega ožiga - venenje listov in sušenje poganjkov 